\title{
The effect of pilates on body awareness, activity level, aerobic capacity and balance in healthy young adults
}

\section{Pilatesin sağlıklı genç yetişkin bireylerde vücut farkındalığı, aktivite düzeyi, aerobik kapasite ve denge üzerine etkisi}

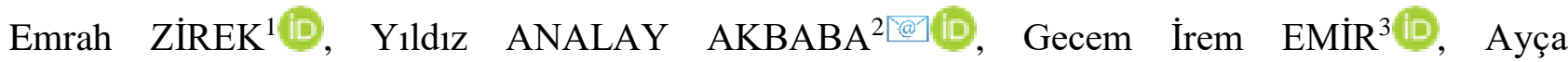 ASLANTÜRK $^{4}$ (D) Merve KOYUNCU ${ }^{5}$ (D)}

\author{
${ }^{1}$ Bingol University, Faculty of Health Sciences, 12000, Bingöl-Turkey \\ ${ }^{2}$ Istanbul University-Cerrahpasa, Faculty of Health Sciences, 34147, İstanbul-Turkey \\ ${ }^{3}$ Istanbul University Institute of Health Sciences, 34126, İstanbul-Turkey \\ ${ }^{4}$ Istanbul University Cerrahpasa, Institute of Graduate Studies, 34320, İstanbul-Turkey \\ ${ }^{5}$ Florence Nightingale Hospital, 34381, İstanbul-Turkey
}

Atıf gösterme/Cite this article as: Zirek E, Analay Akbaba Y, Emir G.İ, Aslantürk A, Koyuncu M. The effect of pilates on body awareness, activity level, aerobic capacity and balance in healthy young adults. ADYÜ Sağllk Bilimleri Derg. 2021;7(2):129-135. doi:10.30569.adiyamansaglik.934499

\begin{abstract}
Aim: In this study, it was aimed to investigate the effects of Reformer Pilates on body awareness, activity level, aerobic capacity and balance in young adults.

Materials and Methods: Participants were consisted of Reformer Pilates (individuals who received a program of muscle strengthening and flexibility exercises; $n=82)$ and sedentary groups $(n=87)$. Body Awareness Questionnaire (BAQ), International Physical Activity Questionnaire Short Form (IPAQSF), YMCA 3-Minute Step Test, Single-Limb Stance Test (SLST), and Functional Reach Test (FRT) were used in the evaluations of the participants.

Results: A statistically significant difference was found in favor of the Reformer Pilates group in the scores of BAQ, IPAQ-SF mild level activity, YMCA 3-Minute Steps Test, SLST with eyes closed, and lateral FRT scores $(p<0.05)$. In the sedentary group, heart rate change after the YMCA 3 min Step Test was statistically significantly higher $(p=0.001)$.

Conclusion: Body awareness, aerobic performance, and balance scores were found to be better in individuals who practiced Reformer Pilates than in sedentary individuals.
\end{abstract}

Keywords: Reformer Pilates, Functionality, Balance, Body Awareness, Exercise.
Öz

Amaç: Bu çalışmada, genç erişkin bireylerde Reformer Pilatesin vücut farkındalığı, aktivite düzeyi, aerobik kapasite ve denge üzerine etkilerinin incelenmesi amaçlanmıştır.

Gereç ve Yöntem: Katılımcılar Reformer Pilates (kas güçlendirme ve fleksibilite egzersizi programı alan bireyler; $\mathrm{n}=82)$ ve sedanter $(n=87)$ gruplarından oluşmaktaydı. Katılımcıların değerlendirmesinde Vücut Farkındalığı Anketi (VFA), Uluslararası Fiziksel Aktivite Anketi Kisa Form (UFAA-KF), YMCA 3Dakika Basamak Testi Tek Ayak Üzerinde Durma Testi (TAÜDT) ve Fonksiyonel Uzanma Testi (FUT) kullanıldı.

Bulgular: VFA, UFAA-KF hafif düzey aktivite, YMCA 3-Dakika Basamak Testi, gözler kapalı TAÜDT ve yana FUT skorlarında Reformer Pilates grubu lehine istatistiksel olarak anlamlı farklılık bulundu $(p<0,05)$. Sedanter grupta YMCA 3 dakikalık Adım Testi sonrası kalp hızı değişimi istatistiksel olarak anlamlı derecede yüksekti $(p=0,001)$.

Sonuç: Reformer Pilatesi uygulayan bireylerin vücut farkındalığı, aerobik performans ve denge skorlarının sedanter bireylere göre daha iyi olduğu bulunmuştur.

Anahtar Kelimeler: Reformer Pilates; Fonksiyonellik; Denge; Vücut Farkındalığı; Egzersiz.

Yazışma Adresi/Address for Correspondence: Yıldız ANALAY AKBABA, Istanbul University-Cerrahpasa, Faculty of Health Sciences, 34147, İstanbul-Turkey, E-mail: yildizanalay@iuc.edu.tr

Geliş Tarihi/Received:07.05.2021 Kabul Tarihi/Accepted:23.06.2021

Yayım Tarihi/Published online:30.08.2021

Bu eser, Creative Commons Atıf-GayriTicari 4.0 Uluslararası Lisansı ile lisanslanmıștır. Telif Hakkı @ 2021 Adıyaman Üniversitesi Rektörlügü 


\section{Introduction}

The World Health Organization (WHO) recommends physical activities of different severity specific to individuals of different age groups. ${ }^{1}$ There is evidence that regular physical activity reduces the risk of various chronic diseases such as heart attack, stroke, diabetes, and cancer and positively affects overall health by improving mental health and quality of life. ${ }^{1,2}$ Pilates is one of the popular and widespread physical activities throughout the world that can be recommended. ${ }^{3}$ This exercise form has different classifications, such as classical, modern and clinical (modified) Pilates. It can be applied on a Mat or with the help of a tool (Reformer). Pilates is a physical method and a holistic approach that provides mental focus and reduces stress and anxiety. ${ }^{4}$

The number of studies on Pilates is increasing and diverse day by day. Pilates aims to develop body awareness through movements that are controlled, concentrated and accurately initiated, and complemented by appropriate efforts. ${ }^{5}$ It is reported that Pilates positively affects the aerobic parameters of individuals with both healthy and limited aerobic capacity. ${ }^{6}$ In addition to the effects on muscle strength and endurance, it is reported that Pilates improves balance by providing different proprioceptive inputs. Pilates may also improve balance scores regardless of the physical activity history of individuals. ${ }^{7-10}$

In the literature, Pilates-related studies generally include individuals with chronic diseases, geriatric and obese individuals who are at risk of falling, and only the effect of Pilates on certain parameters has been investigated. $^{11-15}$ Although it has been reported that Reformer Pilates increase body awareness, static and dynamic balance, general body flexibility, muscle strength, joint range of motion, and posture, studies evaluating different parameters together are insufficient. ${ }^{7,16,17}$ The number of studies evaluating the effectiveness of Pilates on multi-faceted health components in groups including young and healthy subjects is limited. ${ }^{18}$ Therefore, in our study, we aimed to investigate the effects of Reformer Pilates on body awareness, activity level, aerobic capacity, and balance in young adult healthy individuals.

\section{Materials and Methods}

\section{The type of the study}

Our study was designed as a descriptive observational study.

\section{The population and the sample of the study}

In our study, $G^{*}$ Power Analysis Program was used to determine the sample size. According to the results obtained from the study conducted by Tolnai et al., the effect size was determined as 0.129 . With $95 \%$ power (Type-1 error=0.05), the number of participants was calculated as 124 participants (62 participants for each group). ${ }^{14}$

This study was a single-center, controlled study. Between 10.07.2020 and 10.01.2021, 90 individuals who perform Reformer Pilates regularly for at least 2 months and 98 individuals without any regular exercise or sports history in a similar age group were evaluated in terms of eligibility. Of these individuals, thirteen refused to participate in the study (Reformer Pilates group: $n=5$; Sedentary Group: $n=8$ ). In addition, 6 individuals did not meet the inclusion criteria (3 Active athletes in Reformer Pilates Group; 3 with Chronic disease in sedentary Group) After the eligibility assessment, a total of 169 participants were included in the study (82 participants who performed Reformer Pilates regularly and 87 sedentary participants). The exercises were performed by a certified physiotherapist.

The inclusion criteria of the study were: to be between the ages of 18-30, to have the cognitive ability to understand and interpret the questions in the questionnaires, to perform only the Reformer type of Reformer Pilates for at least 2 months for the Reformer Pilates group and not to perform any regular exercise in the last 2 months for the sedentary group. Participants who had chronic, neurological, orthopedic, systemic, and/or pulmonary disease and individuals who had any other exercise/sport except Reformer Pilates (for the Reformer Pilates group) were excluded from the study. 
Written and oral information was given to all participants and written informed consent was obtained from all subjects.

\section{Exercise Protocol}

Reformer pilates group consisted of the individuals who received a standard program that included muscle strengthening and flexibility exercises for at least 2 months, 3 days a week.

The exercises consisted of a program that included muscle strengthening and flexibility exercises. The Reformer Pilates focused on spinal stabilization, muscular strength, flexibility, balance, proprioception, and body awareness. The exercises were performed in different positions such as lying down, sitting and standing. Each Reformer Pilates session lasted approximately 60 minutes. The subjects performed warm-up exercises on the mat for 10 minutes, Reformer exercises for 40 minutes, and cooling exercises on the mat for 10 minutes. The intensity of the exercises was increased by changing the resistance of the springs and adding different positions. The number of repetitions of exercises was increased according to individual progress. The Reformer Pilates program was standard and all sessions were performed by the same physiotherapist.

\section{Data collection tools}

The demographic and clinical characteristics of the participants were evaluated by using the "Participant Report Form". In this form, demographic information such as body mass index (BMI), marital status, the habit of smoking, chronic disease, and regular sports history were examined.

The body awareness of the participants was evaluated by using the Body Awareness Questionnaire (BAQ) and level of physical activity with the International Physical Activity Questionnaire-Short Form (IPAQ$\mathrm{SF})$. For the functional assessments, Young Men's Christian Association 3 Minute Step Test was used for the assessment of aerobic capacity, the Single-Limb Stance Test (SLST) for static balance, and the Functional Reach Test for the dynamic assessment of the participants.
The body awareness questionnaire (BAQ) is a questionnaire aimed at determining the level of sensitivity of individuals to body composition. The questionnaire consists of 18 items, and each item is rated between 1 and 7 by the participants $(1=$ not true at all, $7=$ completely true). The total score is a maximum of 126 and a high score taken from the scale indicates that the individual's body awareness level is high. , $^{8} 19$

The International Physical Activity Questionnaire-Short Form (IPAQ-SF) is a questionnaire that consists of 7 questions and 4 categories. The questionnaire categories the activities as mild, moderate, and vigorous intensity. For each category, duration (minutes), frequency (days), and metabolic equivalent (MET) values are multiplied together to obtain a total score. In the calculation of IPAQ-SF data, activity levels are used as 3.3 MET for walking, 4.0 MET for moderate to vigorous activity, and 8.0 MET for vigorous activity. ${ }^{9}$

The Young men's Christian Association (YMCA) 3 minute step test is a useful and easily administered assessment for measuring aerobic capacity. A $30.50 \mathrm{~cm}$ (12 in) step, stopwatch, and metronome (96 beats/min) were used for this test. Each participant was asked to step up and down (Up-Up-DownDown) with each beat of the metronome for 3 minutes. At the end of the test, the participant immediately sat down, and the heart rate 5 seconds after sitting was measured for 1 minute. ${ }^{10}$

The Single-Limb Stance Test (SLST) was used to evaluate the static balance of the participants. Participants were asked to stand on one leg for 60 seconds with their arms crossed over their chests and the time they could stay in this position was recorded with a stopwatch. The test was applied 3 times for both the right and left legs, with the eyes open and closed. The test was terminated and the average time obtained was recorded when the participant lost his/her balance or touched their foot on the ground/the ankle of their stance limb. ${ }^{20}$

Functional Reach Test (FRT); the test was performed to evaluate the dynamic balance of 
the participants in two directions: forward and lateral. The participants were asked to stand while their dominant sidearm closed but without touching the wall. The shoulder was in $90^{\circ}$ flexion, the elbow was in extension, while the dorsal hand was facing the wall. The tip of the 3rd finger was marked on the wall, the participant asked to lie as far as he/she could without lifting his/her heels. The new location of the 3.th finger was marked, the difference between the start and endpoint was measured and scored. ${ }^{21}$

\section{Data analysis}

The statistical analysis of the study was made by using the SPSS version 21.0 (SPSS inc. Chicago, IL, USA) package program. In the data set, variables were defined as percent (\%), mean and standard deviation (SD). The Shapiro Wilk test was used to examine the distribution of the data. The Chi-Square test was used to compare the categorical variables. Independent Sample t-Test was used to evaluate independent data found by the
Normal distribution. Values below 0.05 were considered statistically significant.

\section{Results}

A total of 169 participants were included in the study, including 82 subjects who regularly performed Reformer Pilates and 87 sedentary individuals. All of the participants were female. The mean age of the participants was $26.93 \pm 4.52$ years in the Reformer Pilates group and $24.67 \pm 4.70$ years in the sedentary group. BMI was $21.93 \pm 3.08 \mathrm{~kg} / \mathrm{m}^{2}$ in the individuals in the sedentary group and $22.34 \pm 3.44 \mathrm{~kg} / \mathrm{m}^{2}$ in the Reformer Pilates group.

In the comparison of the demographic characteristics of the groups, there was no statistically significant difference in terms of age, BMI, marital status, and presence of chronic disease $(p>0.05)$. Smoking and exercising habits were more in the Reformer Pilates group (respectively: $p=0.008$; $p=0.038$ ). The weekly exercise frequency of the subjects in the Reformer Pilates group was found to be $3.09 \pm 0.83$ days (Table 1 ).

Table 1. Comparison of the demographic and clinical characteristics of the groups.

\begin{tabular}{|c|c|c|c|c|}
\hline \multicolumn{2}{|l|}{ Variables } & $\begin{array}{l}\text { Reformer Pilates } \\
(\mathrm{n}=82)\end{array}$ & Sedentary $(n=87)$ & $p$ \\
\hline \multicolumn{2}{|l|}{ Age (Mean \pm SD) (year) } & $26.9 \pm 4.52$ & $24.7 \pm 4.7$ & $0.479 *$ \\
\hline \multicolumn{2}{|l|}{ BMI $\left(\right.$ Mean \pm SD) $\left(\mathrm{kg} / \mathrm{m}^{2}\right.$} & $22.34 \pm 3.44$ & $21.93 \pm 3.08$ & $0.414^{*}$ \\
\hline \multicolumn{2}{|c|}{$\begin{array}{l}\text { Reformer Pilates Frequency (day/week) } \\
(\text { Mean } \pm \text { SD) }\end{array}$} & $3.09 \pm 0.83$ & - & \\
\hline \multicolumn{2}{|c|}{ Reformer Pilates Session Duration (Mean \pm SD) } & $50.95 \pm 1.16$ & - & \\
\hline \multirow[t]{3}{*}{ Marital Status: n (\%) } & Married & $30(36.6)$ & $25(28.7)$ & \multirow{3}{*}{$0.549 * *$} \\
\hline & Single & $51(62.2)$ & $61(70.1)$ & \\
\hline & Divorced & $1(1.2)$ & $1(1.1)$ & \\
\hline \multirow[t]{2}{*}{ Smoking: $\mathrm{n}(\%)$} & Yes & $23(28.0)$ & $13(14.9)$ & \multirow[t]{2}{*}{$\mathbf{0 . 0 3 8} * *$} \\
\hline & No & $59(72.0)$ & $74(85.1)$ & \\
\hline \multirow[t]{2}{*}{ Chronic Disease: $\mathrm{n}(\%)$} & Yes & $23(28.0)$ & $19(21.8)$ & \multirow[t]{2}{*}{$0.351 * *$} \\
\hline & No & $59(72.0)$ & $68(78.2)$ & \\
\hline \multirow[t]{2}{*}{ Sports History: n (\%) } & Yes & $41(50)$ & $26(29.9)$ & \multirow[t]{2}{*}{$0.008 * *$} \\
\hline & No & $41(50)$ & $61(70.1)$ & \\
\hline
\end{tabular}

SD: Standard Deviation. BMI: Body Mass Index

* Independent Sample t-Test.

**: Chi-Square test.

$\mathrm{p}<0.05$ significant.

The comparison of the body awareness level, physical activity level, and aerobic performance of the groups is shown in Table 2. A statistically significant difference was found in the BAQ and IPAQ-SF mild level activity scores in the Reformer Pilates group (respectively: $\quad p<0.00 ; \quad p=0.022$ ). The difference in the IPAQ-SF moderate and vigorous levels and the IPAQ-SF total score was not statistically significant $(p>0.05)$. In the sedentary group, heart rate change after the YMCA 3 min Step Test was statistically significantly higher $(p=0.001)$. 
Table 2. Comparison of body awareness level, activity level and aerobic performance of groups.

\begin{tabular}{lllc}
\hline & $\begin{array}{l}\text { Reformer Pilates }(\mathbf{n = 8 2}) \\
(\text { Mean } \pm \text { SD) }\end{array}$ & $\begin{array}{l}\text { Sedentary }(\mathbf{n = 8 7}) \\
(\text { Mean } \pm \text { SD })\end{array}$ & $\boldsymbol{p}^{*}$ \\
\hline BAQ & $104.45 \pm 16.63$ & $88.74 \pm 16.47$ & $<\mathbf{0 . 0 0 1}$ \\
\hline IPAQ-SF Total & $1916.12 \pm 1827.70$ & $1815.03 \pm 1293.87$ & 0.677 \\
\hline IPAQ-SF Mild & $1347.72 \pm 1541.01$ & $896.23 \pm 945.61$ & $\mathbf{0 . 0 2 2}$ \\
\hline IPAQ-SF Moderate & $405.61 \pm 506.65$ & $361.71 \pm 657.87$ & 0.627 \\
\hline IPAQ-SF Vigorous & $353.29 \pm 173.25$ & $333.10 \pm 130.28$ & 0.395 \\
\hline HR after the YMCA 3MST & $108.95 \pm 14.63$ & $123.77 \pm 21.43$ & $\mathbf{0 . 0 0 1}$ \\
\hline
\end{tabular}

SD: Standard Deviation, BAQ: Body Awareness Questionnaire IPAQ-SF: International Physical Activity Questionnaire Short Form, YMCA 3MST: Young Men's Christian Association 3 Minute Step Test; HR: Heart Rate.

* Independent Sample t-Test. $\mathrm{p}<0.05$ significant.

The comparisons of the static and dynamic balance scores of the groups are given in Table 3. There was a statistically significant difference in the eyes' closed SLST scores for both limbs in the Reformer Pilates group $(p<0.001 ; p<0.001)$. The lateral FRT score was significantly higher in the Reformer Pilates group $(p=0.003)$.

Table 3. Comparison of static and dynamic balance scores of groups.

\begin{tabular}{llllc}
\hline & & $\begin{array}{l}\text { Reformer Pilates (n } \\
\mathbf{9 8 2} \\
(\text { 8ean } \pm \text { SD) }\end{array}$ & $\begin{array}{l}\text { Sedentary }(\mathbf{n}=\mathbf{8 7}) \\
(\text { Mean } \pm \text { SD) }\end{array}$ & $\boldsymbol{p}^{*}$ \\
\hline SLST; Eyes Open (sec) & Right & $58.02 \pm 8.27$ & $57.33 \pm 7.05$ & 0.559 \\
\cline { 2 - 5 } & Left & $57.30 \pm 10.09$ & $56.75 \pm 8.07$ & 0.695 \\
\hline SLST; Eyes Closed Balance (sec) & Right & $38.93 \pm 21.52$ & $26.67 \pm 18.29$ & $<\mathbf{0 . 0 0 1}$ \\
\cline { 2 - 5 } & Left & $37.63 \pm 21.97$ & $23.84 \pm 18.49$ & $<\mathbf{0 . 0 0 1}$ \\
\hline Functional Reach Test (cm) & Forward & $36.92 \pm 7.09$ & $34.88 \pm 6.93$ & 0.61 \\
\cline { 2 - 5 } & Lateral & $27.14 \pm 5.08$ & $24.83 \pm 4.96$ & $\mathbf{0 . 0 0 3}$ \\
\hline
\end{tabular}

SD: Standard Deviation. SLST: Single-Limb Stance Test, sec: second, cm: centimeter.

* Independent Sample t-Test. $\mathrm{p}<0.05$ significant.

\section{Discussion}

This study investigated the effect of Reformer Pilates on body awareness, physical activity level, aerobic capacity, and balance in young adults. According to the results, body awareness, balance, and aerobic capacity were found better in individuals who regularly exercise Reformer Pilates compared to sedentary individuals.

Adams $\mathrm{M}$ et al. aimed to investigate the experiences of their students in a semesterlong Pilates mat class and the results showed that Pilates increased postural awareness in $78 \%$ of the students and also supported both mental and physical well-being. ${ }^{22}$ In a similar study made by Atılgan et al., university students that applied Pilates during a semester showed improvement in body awareness and flexibility scores. ${ }^{23}$ Although there was also a control group in our study; similar to these results, we found that individuals who performed regular Reformer Pilates had better body awareness scores.

Johnson E.G. et al. applied a 10-session Pilates-based exercise program to healthy individuals and a significant improvement was found in dynamic balance. ${ }^{17}$ Erden A. et al. reported that an 8-week Pilates program had significant effects on the improvement of dynamic and static balance in healthy adults. ${ }^{8}$ In a study made by Kloubec et al., 12 weeks of Pilates were performed on young adults, and the results showed significant improvement in posture and balance. ${ }^{7}$ One of the aims of our study was to evaluate the effect of regular Pilates practice on balance parameters. In our study, similar to the literature, balance results were found significantly better in individuals who have regular exercise habits for 3 days a week for at least two months.

Fernández et al. In a meta-analysis conducted in 2019, it was stated that Pilates increased aerobic performance regardless of health status. ${ }^{6}$ Diamantoulla et al. compared two different types of Pilates applications (aquatic and ground), and similar improvements were found in both groups in terms of aerobic capacity, strength, endurance, and balance, while the percentage 
of fat loss and the development of flexibility was higher in the ground group. Rayes et al. investigated the effects of Pilates on aerobic capacity and reported a significant improvement in aerobic capacity parameters after an 8-week Pilates program in individuals without regular exercise habits. ${ }^{12}$ In our study where we also investigated the effect of Pilates application on aerobic performance. The results of our study were consistent with the literature. Although the number of smokers was higher in the Reformer Pilates group, it was found that aerobic performance and balance scores were better than sedentary individuals.

In a systematic review made by Hornsby et al in 2020, it was reported that Pilates improve flexibility, strength, and postural control in children and young adults while minimizing muscle energy expenditure and improving the level of physical activity. ${ }^{24}$ García-Soidán et al. stated that a 12-week Pilates application is a method that increases physical activity and is easy to access and apply. ${ }^{25}$ In our study, we also investigated the effect of Pilates on physical activity level. The results showed that only mild-level activity was higher in the Pilates group compared to the sedentary group, while the medium, vigorous, and general activity levels were at a similar level in both groups. These results showed that individuals who perform Reformer Pilates can have higher levels of body awareness, aerobic capacity, and balance than sedentary individuals, even if the activity intensity is similar.

A key strength of the present study is that it represents a comprehensive examination of the effect of Reformer Pilates on multiple health-related components such as body awareness, physical activity level, aerobic capacity, and balance in healthy young adults. Another strength of this study is the presence of a control group. The limitation of our study is the absence of long-term follow-up. Future studies are recommended to include long-term follow-up and compare different Reformer Pilates applications with larger sample sizes.

\section{Conclusion}

Reformer Pilates is an effective method to improve body awareness, aerobic capacity, and balance. Especially when compared with sedentary individuals, it has been found that Reformer Pilates has a significant positive effect. We think that recommending Reformer Pilates as a component of preventive rehabilitation will be beneficial in terms of public health.

\section{Ethics Committee Approval}

The ethical approval of the study was obtained from Istanbul UniversityCerrahpaşa, Faculty of Medicine, NonInvasive Clinical Research Ethics Committee dated 17.07.2020 with decision number 60350273-605.99-91919. Our research was conducted under the principles of the Declaration of Helsinki.

\section{Informed Consent}

Informed consent was obtained from all subjects. In addition, necessary approvals were obtained from the centers where the data was collected.

\section{Authors' Contributions}

Study Concept / Design: Y.A.A., I.E, A.A., M.K.; Data collecting: I.E, A.A., M.K.; Data analysis and interpretation: E.Z, Y.A.A.; Literature Review: E.Z., Y.A.A., I.E, A.A., M.K; Writers: E.Z., Y.A.A., I.E, A.A., M.K. The final version of this article was read and approved by all authors.

\section{Acknowledgments}

We would like to thank our colleagues who supported the data collection in the study and the participants who voluntarily provided data for the scientific study.

\section{Conflict of Interest}

The authors declare that there is no conflict of interest

\section{Financial Disclosure}

There is no person/organization that financially supports this study.

\section{Statements}

Some of the article data was presented as a verbal presentation at the "International 


\section{Congress of Medicine and Health Sciences" congress made between April 26-28, 2021.}

\section{Peer-review}

\section{Externally peer-reviewed.}

\section{References}

1. Organization WH. Global recommendations on physical activity for health. World Health Organization; 2010.

2. Organization WH. Global action plan on physical activity 2018-2030: more active people for a healthier world. World Health Organization; 2019.

3. Latey P. The Pilates method: history and philosophy. Journal of bodywork and movement therapies. 2001;5(4):275-282.

4. Memmedova K. Impact of Pilates on Anxiety Attention, Motivation, Cognitive function and Achievement of Students: Structural Modeling. Procedia - Social and Behavioral Sciences. 2015;186:544-548.

5. Penelope L. Updating the principles of the Pilates methodPart 2. Journal of Bodywork and Movement Therapies. 2002;6(2):94-101.

6. Fernández-Rodríguez R, Álvarez-Bueno C, Ferri-Morales A, Torres-Costoso AI, Cavero-Redondo I, Martínez-Vizcaíno V. Pilates method improves cardiorespiratory fitness: A systematic review and meta-analysis. Journal of clinical medicine. 2019;8(11):1761.

7. Kloubec JA. Pilates for improvement of muscle endurance, flexibility, balance, and posture. The Journal of Strength \& Conditioning Research. 2010;24(3):661-667.

8. Erden A, Altuğ F, Cavlak U. Sağlıklı kișilerde vücut farkındalık durumu ile ağrı, emosyonel durum ve yaşam kalitesi arasındaki ilişkinin incelenmesi. 2013.

9. Öztürk M. Üniversitede Egitim-Ögretim Gören Ögrencilerde Uluslararasi Fiziksel Aktivite Anketi'nin Geçerliligi Ve Güvenirligi Ve Fiziksel Aktivite Düzeylerinin Belirlenmesi (Research on Reliability and Validity of International Physical Activity Questionnaire and Determination of Physical Activity Level in University Students). Ankara: Hacettepe Üniversitesi Saglık Bilimleri Enstitüsü. 2005.

10. Salmon M, Salmon C, Masoda M, et al. Albendazole treatment improves work capacity in women smallholder farmers infected with hookworm: a double-blind randomized control trial. The American journal of tropical medicine and hygiene. 2018;98(5):1419-1426.

11. Kaesler D, Mellifont R, Kelly PS, Taaffe D. A novel balance exercise program for postural stability in older adults: a pilot study. Journal of Bodywork and Movement Therapies. 2007;11(1):37-43.

12. Rayes ABR, de Lira CAB, Viana RB, et al. The effects of Pilates vs. aerobic training on cardiorespiratory fitness, isokinetic muscular strength, body composition, and functional tasks outcomes for individuals who are overweight/obese: a clinical trial. PeerJ. 2019;7:e6022.

13. Wells C, Kolt GS, Marshall P, Hill B, Bialocerkowski A. The effectiveness of Pilates exercise in people with chronic low back pain: a systematic review. Plos one. 2014;9(7):e100402.

14. Tolnai N, Szabó Z, Köteles F, Szabo A. Physical and psychological benefits of once-a-week Pilates exercises in young sedentary women: A 10-week longitudinal study. Physiology \& behavior. 2016;163:211-218.

15. Duff WR, Andrushko JW, Renshaw DW, et al. Impact of Pilates exercise in multiple sclerosis: A randomized controlled trial. International journal of MS care. 2018;20(2):92-100.

16. Gallagher SP, Kryzanowska R, Speleotis S. The Pilates method of body conditioning: Introduction to the core exercises. BainBridge Books; 1999.

17. Johnson EG, Larsen A, Ozawa H, Wilson CA, Kennedy KL. The effects of Pilates-based exercise on dynamic balance in healthy adults. Journal of bodywork and movement therapies. 2007;11(3):238-242.

18. Cruz-Ferreira A, Fernandes J, Laranjo L, Bernardo LM, Silva A. A systematic review of the effects of Pilates method of exercise in healthy people. Archives of physical medicine and rehabilitation. 2011;92(12):2071-2081.
19. Shields SA, Mallory ME, Simon A. The body awareness questionnaire: reliability and validity. Journal of personality Assessment. 1989;53(4):802-815.

20. Wongsaya E, Chamnongkich S. Validation of a one-leg sit-tostand test for the measurement of knee extensor muscle strength and endurance in young adults. Bull Chiang Mai Assoc Med Sci. 2012;45:79-88.

21. Lin MR, Hwang HF, Hu MH, Wu HDI, Wang YW, Huang FC. Psychometric comparisons of the timed up and go, one-leg stand, functional reach, and Tinetti balance measures in community-dwelling older people. Journal of the American Geriatrics Society. 2004;52(8):1343-1348.

22. Adams M, Caldwell K, Atkins L, Quin R. Pilates and mindfulness: a qualitative study. Journal of Dance Education. 2012;12(4):123-130.

23. Atilgan E, Tarakci D, Mutluay F. Examining the postural awareness and flexibility changes in physical therapy students who took clinical Pilates class. Pakistan journal of medical sciences. 2017;33(3):640.

24. Hornsby E, Johnston LM. Effect of Pilates intervention on physical function of children and youth: a systematic review. Archives of physical medicine and rehabilitation. 2020;101(2):317-328

25. García-Soidán JL, Giraldez VA, Zagalaz JC, Lara-Sánchez A. Does Pilates exercise increase physical activity, quality of life, latency, and sleep quantity in middle-aged people? Perceptual and motor skills. 2014;119(3):838-850. 